\title{
MAVIS REIMER, NYALA ALI, DEANNA ENGLAND OCH MELANIE DENNIS UNRAU (RED.) SERIALITY AND TEXTS FOR YOUNG PEOPLE \\ The Compulsion to Repeat
}

Houndmills: Palgrave Macmillan, 2014 (312 s.)

För att definitioner och kritiska begrepp ska vara användbara måste de avslöja något som annars inte skulle synas. De måste vara tillräckligt generösa och vittomfattande för att dittills dolda samband och strukturer ska kunna uppenbaras; samtidigt måste de vara tillräckligt smala och begränsande för att det ska vara meningsfullt att använda dem.

Jag tänker på det när jag läser antologin Seriality and Texts for Young People: The Compulsion to Repeat. Det är ett samlingsverk där de enskilda kapitlen ofta är spännande och välgjorda, men där helheten spretar betänkligt just för att de centrala begreppen, "serialitet" och "upprepning", är alltför stora och intetsägande. Vilka kulturella uttryck, litterära former eller språkliga strukturer är inte beroende av någon form av upprepning? Jaques Derrida, som inledningsvis åberopas av författarna, slår fast att det är upprepning som möjliggör talat och skrivet språk. Och även andra auktoriteter - från Marx, Freud och Kierkegaard, till Butler, Deleuze och Guattari - har påvisat hur centrala repetition och serialitet är för oss människor. Men om det nu är på det viset kan man undra om inte Mavis Reimer och C:o har spänt upp ett begreppsparaply som är alldeles för stort för dem. För vad skulle över huvud taget kunna hamna utanför?

Utgångspunkten för projektet är annars vällovligt: att belysa och beforska bokserier för barn och ungdomar, en publikationsform som allt som oftast ses över axeln av vuxenvärlden. Egentligen är det väl bara Victor Watson, som i sin Reading Series Fiction (2000) ändå försökt ta ett samlat grepp på bokserier. Hans uppdelning i successiva och progressiva bokserier är fortsatt användbar även om 
man i en nordisk kontext ofta föredrar benämningarna "oändliga" och "ändliga" (se t.ex. Stine Reinholdt Hansens avhandling Når börn vaelger litteratur från 2014).

Serier som är successiva/oändliga kännetecknas av att ingen direkt utveckling sker genom serien, utan varje bok utgör endast en variation av ett grundkoncept. Enid Blytons Fem-böcker är ett bra exempel på sådana här bokserier. I serier som är progressiva/ ändliga sker däremot en utveckling och varje bok bygger på den föregående, som J. K. Rowlings Harry Potter-böcker. Alternativt kan varje bok bidra med en pusselbit till helheten, som sker i C. S. Lewis Narnia-böcker eller Tove Janssons Mumin-böcker. Inget skiljer egentligen bokserier från enskilda romaner mer än själva publikationsformen. Min egen position här är att det är helt missvisande att tala om Mumin, Anne på Grönkulla, Harry Potter och så vidare som bokserier; de egentliga bokserierna är de successiva. Det är för övrigt just den här typen av litteratur som ännu inte behandlats på ett genomgripande sätt av forskningen.

Tyvärr behandlas inte den här centrala typen av successiva bokserier - de" oändliga" - i någon större utsträckning i den föreliggande Seriality-antologin heller. Den digra inledningen gör det inte, och av de tretton kapitlen är det egentligen bara två som ägnas successiva bokserier, nämligen Frank L. Baums Trollkarlen från Oz-böcker och den historiskt och nationellt orienterade Dear Canada-serien. Och ingen av dessa bokserier är särskilt typiska för den oändliga, successiva bokserien.

I Oz-kapitlet ligger fokus på Plåtmannen och hans olika versioner eller inkarnationer i Oz-serien. Just genom att en mekanisk varelse kan dupliceras om och om igen kan den ses som en sinnebild för serialitet, men också för konsten och litteraturen i senmoderniteten. Och kanske också för människan och hennes villkor. Kapitelförfattaren Laurie Langbauer skriver att Oz-seriens budskap är att

maskiner konstruerar samtidigt som de alienerar. Mekaniska människor som Plåtmannen antyder att människor hela tiden varit maskiner eller att [...] maskiner är bättre människor. Även om samtida kritiker ansåg att Oz-böckernas repetitiva karaktär förminskade dem visar Trollkarlen från Oz-serien att serialitet utgör en möjlighet för det moderna varat. (51)

Här bränner det till. Langbauer kopplar alltså en serie böcker som präglas av upprepning till en av dess centrala karaktärer, Plåtmannen, som även han kan upprepas/dupliceras, och visar att detta tema 
(för det är det också) pekar på något som är centralt för vår identitet och kultur, och vidare att det seriella inte nödvändigtvis måste leda till kulturpessimism, utan att där också kan finnas positiva värden.

Även kapitlet om de fiktiva Dear Canada-dagböckerna är intressant. Författaren, charlie peters, avkodar där vilka tematiska repetitioner som byggts in i serien. Det handlar mycket om rädslor. Som författaren skriver kan man undra om "nationalistiska känslor nödvändigtvis handlar om att vara rädd". Rädslan är dessutom paradoxalt nog ofta riktad just mot staten. Flickorna som skriver dagbok hör till olika "nationella" minoriteter - cree, métis, skottar, judar och så vidare - som alla under olika historiska perioder förföljts eller haft svårt i Kanada. Trots den inneboende kritiken mot nationalstaten, i det här fallet Kanada, upprättar ändå serien som helhet ett "Dear Canada"-förhållande till staten som inte är så ironiskt som det låter. Kanske kan man säga att det överordnade budskapet är att historien (och läsningen av de här böckerna) lär att alla har förfäder som någon gång har haft skäl att vara rädda och att vi därför kan förenas i den kunskapen.

Jag har argumenterat för att successiva bokserier förtjänar en ordentlig genomlysning, något som inte tillhandahålls av den föreliggande Seriality-antologin. Jag har också uppehållit mig vid två analyser av successiva bokserier. Det betyder inte att övriga kapitel i studien är ointressanta, bara att de enligt min mening siktar vid sidan av målet. Där finns texter om teman i Anne på Grönkulla-serien, om intertextualitet och självreferentialitet i Superhjälte-serietidningar, och om skulpturer som sekvenskonst. Ett kapitel tar upp Harry Potter, och hur en detalj i en bok visar sig vara betydelsebärande i en senare bok, även detta alltså betraktat som en form av repetition. Flera bidrag tar upp remediering som en typ av repetition: den lilla sjöjungfrun, vampyrjägaren Buffy. Ett kapitel talar om MP3, egentligen digitalisering, som repetition. Som dessa exempel visar, finns nästan ingenting i litteraturen som inte kan kvalificeras som repetition och serialitet.

$\mathrm{Nu}$ har jag visst upprepat mig. Se där, ännu ett exempel på serialitet...

Björn Sundmark

Professor i engelsk litteratur

Malmö högskola 